\title{
PENERAPAN PEMBERIAN HIBAH BERDASARKAN PASAL 920 KITAB UNDANG-UNDANG HUKUM PERDATA DILIHAT DARI ASAS LEGITIEME PORTIE (STUDI KASUS: PUTUSAN MAHKAMAH AGUNG REPUBLIK INDONESIA NOMOR 2954K/PDT/2017)
}

\author{
Vanessa \\ (Mahasiswa Program S1 Fakultas Hukum Universitas Tarumanagara) \\ (E-mail: vanessaalim10@gmail.com)
}

\section{Dr. S. Atalim, S.H., M.H.}

(Corresponding Author)

(Dosen Fakultas Hukum Universitas Tarumanagara. Meraih Sarjana Hukum pada Fakultas Hukum Universitas Indonesia, Magister Hukum pada Fakultas Hukum Universitas Indonesia, Doktor (Dr.) pada Fakultas Hukum Universitas Parahyangan)

(E-mail: st_atalim@yahoo.com)

\begin{abstract}
The problem that often occurs in the case of grants is that legal grants are often found or grants that are legally flawed or canceled. The event of a grant which was declared legally flawed was also found in the case of the Decision of the Supreme Court of the Republic of Indonesia Number 2954K/Pdt/2017. Article 920 of the Civil Code about reduced, by which the article is not listed in the decision. On this basis, a problem arises namely how the application of grants based on Article 920 of the Civil Code can be seen from the principle of legal inheritance share. In answering these problems, the author uses normative legal research methods. Based on the results of the study, it can be seen that with the cancellation of the grant deed by the court's decision and if the heirs who demanded the cancellation of the grant be accompanied by demanding a legal inheritance share, a reduction must be made. Then the author can conclude that the implementation of Article 920 of the Civil Code important to be carried out by the heirs concerned, because by the judge's decision regarding the distribution according to legal inheritance share, so the Article 920 of the Civil Code automatically applicable. The advice that can be given is better for the community to distribute inheritance and provide grants during their lifetime in a fair and equitable manner to avoid problems regarding the grant being declared null and void.
\end{abstract}

Keywords: Grant giving, Reduced, Legal Inheritance Share

\section{PENDAHULUAN}

\section{A. Latar Belakang}

Hukum waris merupakan salah satu bidang hukum yang sulit untuk dipisahkan dari kehidupan seseorang. Hal tersebut dikarenakan dengan 
Volume 2 Nomor 2, Desember 2019

E-ISSN : 2655-7347

meninggalnya seseorang, maka terjadilah perpindahan kekayaan dari seseorang yang telah meninggal tersebut kepada para ahli warisnya. Hadirnya keadaan tersebut, tidak menutup kemungkinan akan terjadi perselisihan di antara para ahli warisnya pada masa pembagian waris. Sehingga hukum waris memegang peranan cukup penting dalam menegakkan keadilan apabila terjadi perselisihan mengenai pembagian harta warisan serta menjadi suatu bidang hukum yang sulit dipisahkan dari kehidupan seseorang.

Hingga saat ini, hukum waris di Indonesia masih sangat beragam. Hal tersebut tampak dalam adanya pembagian tiga sistem hukum kewarisan yaitu hukum waris adat, hukum waris Islam dan hukum waris barat. Tentunya dengan adanya perbedaan sistem hukum kewarisan tersebut, terdapat pula perbedaan forum pengadilan yang dapat digunakan. Pengadilan yang digunakan untuk menyelesaikan perkara hukum waris islam dapat menggunakan Pengadilan Agama. Sedangkan pengadilan yang digunakan untuk menyelesaikan perkara hukum waris barat dapat menggunakan Pengadilan Negeri. Atas dasar tersebut membuktikan bahwa hukum waris di Indonesia masih bersifat pluralistik dan ketiga sistem hukum kewarisan tersebut masih berlaku dan diterapkan dalam kehidupan masyarakat Indonesia.

Hukum waris Eropa yang dimuat dalam Burgerlijk Wetboek (BW) adalah kumpulan peraturan yang mengatur mengenai kekayaan karena wafatnya seseorang, yaitu mengenai pemindahan kekayaan yang ditinggalkan oleh si mati dan akibat dari pemindahan ini bagi orang-orang yang memperolehnya, baik dalam hubungan antara mereka dengan pihak ketiga. ${ }^{1)}$ Dalam KUH Perdata di Indonesia, ada 2 (dua) cara untuk mendapatkan harta warisan, yaitu: (a). Sebagai ahli waris menurut

1) Zainuddin Ali, Pelaksanaan Hukum Waris di Indonesia, (Jakarta: Sinar Grafika, 2008), hal.81. 
Volume 2 Nomor 2, Desember 2019

E-ISSN : 2655-7347

ketentuan undang-undang ( $a b$ intestato), sebagaimana dimaksud dalam Pasal 832 KUH Perdata; (b). Karena seseorang ditunjuk dalam surat wasiat (testamentair), sebagaimana dimaksud dalam Pasal 899 KUH Perdata. ${ }^{2)}$ Berdasarkan hal tersebut perlu diketahui bahwa pokok berlangsungnya pewarisan hanya dapat terjadi apabila ada orang yang mati, ada harta yang ditinggalkan, dan ada ahli waris. ${ }^{3)}$

Namun, selain dari hal-hal yang dapat dilakukan oleh seorang pewaris terhadap harta peninggalannya jika ia telah meninggal, dapat juga ia melakukan pemberian-pemberian kepada seorang pada waktu ia masih hidup. ${ }^{4)}$ Pemberian kepada seorang pada waktu ia masih hidup dinamakan hibah. Hibah yaitu perjanjian sepihak yang dilakukan oleh penghibah ketika hidupnya untuk memberikan sesuatu barang dengan cuma-cuma kepada penerima hibah. ${ }^{5)}$

Hibah sebagaimana yang dimaksud dalam pengertian tersebut berbeda dengan hibah wasiat. Hibah wasiat adalah suatu penetapan yang khusus di dalam suatu testamen, dengan mana yang mewasiatkan memberikan kepada seorang atau beberapa orang: ${ }^{6)}$ (a). Beberapa barang tertentu; (b). Barang-barang dari satu jenis tertentu; (c). Hak pakai hasil dari seluruh atau sebagian, dari harta peninggalannya.

Berdasarkan perbedaan antara hibah dengan hibah wasiat tersebut, dapat diketahui bahwa pelaksanaan pemberian hibah dan hibah wasiat merupakan kegiatan yang cukup sering ditemukan dalam bidang hukum waris. Pelaksanaan pemberian hibah wasiat dan hibah dapat diberikan kepada siapa saja baik kepada ahli waris menurut ketentuan undang-undang

2) Ibid., hal.82.

3) J. Satrio, Hukum Waris, Cetakan ke-2, (Bandung: Alumni, 1992), hal.8.

4) Ali Afandi, Hukum Waris, Hukum Keluarga dan Hukum Pembuktian, Cetakan ke-4, (Jakarta: Rineka Cipta, 2004), hal.30.

5) Eman Suparman, Hukum Waris Indonesia: Dalam Perspektif Islam, Adat, dan BW, (Bandung: Refika Aditama, 2018), hal.113.

6) Ali Afandi, Op.Cit., hal.16. 
Volume 2 Nomor 2, Desember 2019

E-ISSN : 2655-7347

maupun kepada orang lain yang bukan merupakan ahli waris menurut ketentuan undang-undang. Namun, timbulnya permasalahan terkait dalam hal pemberian hibah juga sering terjadi apabila pemberian hibah tersebut dianggap merugikan bagian ahli waris dalam mendapatkan harta warisan yang seharusnya diperoleh sesuai haknya seperti bagian legitieme portie yang terlanggar sebagaimana diatur dalam Pasal 913 KUH Perdata. Sehingga dalam hal pemberian hibah sering ditemukan adanya hibah yang sah secara hukum atau hibah yang cacat secara hukum maupun batal.

Peristiwa dimana pemberian hibah tersebut menjadi cacat secara hukum ditemukan pula dalam suatu kasus Putusan Mahkamah Agung Nomor: 2954K/Pdt/2017. Berdasarkan kasus tersebut dapat diketahui pewarisnya adalah Almarhum Lim Hian Kang dan Almarhumah Tjoa Ay Nio yang telah menikah dan semasa hidupnya memiliki harta bersama berupa sebidang tanah dan bangunan rumah. Pernikahan mereka memiliki keturunan 5 (lima) orang anak kandung sebagai ahli waris yang bernama Lim In Nio (Euphemia Megasari) sebagai Tergugat, Lim Bie Nio (Risa Pahala) sebagai Penggugat pertama, Soeytek (Jemmy Malimar), Lim Le Tjoe sebagai Penggugat kedua, serta Le Hong (Grace Malimar). Dalam pernikahan mereka juga memiliki seorang anak angkat bernama Tjoei Tjoa.

Permasalahan dalam kasus tersebut terjadi dikarenakan setelah Almarhum Lim Hian Kang meninggal dan Almarhumah Tjoa Ay Nio meninggal, barulah diketahui bahwa tanah dan bangunan rumah tersebut telah dihibahkan oleh Almarhumah Tjoa Ay Nio kepada Tergugat tanpa sepengetahuan dan persetujuan dari Para Penggugat. Atas dasar tersebut Para Penggugat tidak terima dan merasa dirugikan karena tanah dan bangunan rumah yang dihibahkan tersebut merupakan harta warisan peninggalan dari Almarhum Lim Hian Kang dan Almarhumah Tjoa Ay Nio yang belum dibagi, serta pemberian hibah atas harta warisan yang 
Volume 2 Nomor 2, Desember 2019

E-ISSN : 2655-7347

belum dibagi tersebut telah melanggar legitieme portie yang merupakan hak Para Penggugat sebagai ahli waris ab intestato dalam menerima harta warisan.

Sebagaimana hal yang telah terurai tersebut, maka Pengadilan Negeri Jakarta Pusat telah memberikan Putusan Nomor: 257/Pdt.G/2015/PN. Jkt.Pst tanggal 22 Desember 2015 dengan amar putusan menolak eksepsi Tergugat untuk seluruhnya dan mengabulkan gugatan Para Penggugat untuk sebagian serta menyatakan hibah tersebut cacat secara hukum dan hibah tersebut dinyatakan batal. Selanjutnya pada tingkat banding atas permohonan Tergugat putusan Pengadilan Negeri tersebut telah dikuatkan oleh Pengadilan Tinggi Jakarta dengan Putusan Nomor: 435/PDT/2016/PT DKI tanggal 12 Oktober 2016. Setelah melalui tingkat banding tersebut, diajukanlah kasasi ke Mahkamah Agung dan dinyatakan bahwa berdasarkan pertimbangan-pertimbangan yang ada, ternyata putusan judex factie (Pengadilan Tinggi) Jakarta dalam perkara ini tidak bertentangan dengan hukum dan/atau undang-undang, maka permohonan kasasi yang diajukan oleh Pemohon Kasasi Euphemia Megasari (Lim In Nio) tersebut haruslah ditolak. Hal tersebutlah yang dituangkan dalam amar putusan pada tingkat kasasi.

Berdasarkan kasus dengan adanya pelanggaran terhadap legitieme portie tersebut, menimbulkan persoalan mengenai terdapatnya suatu ketentuan mengenai inkorting (pengurangan) terhadap harta warisan dengan maksud untuk memenuhi bagian legitieme portie ahli waris mutlak yang berhak atas bagian legitieme portie yang terlanggar atas pemberian hibah yaitu Pasal 920 KUH Perdata, dengan mana pasal tersebut tidak dinyatakan secara tertulis dalam putusan. Berdasarkan hal tersebut, maka Penulis tertarik untuk meneliti topik ini secara komprehensif dan menuangkannya dalam bentuk proposal skripsi dengan judul: "Penerapan Pemberian 
Volume 2 Nomor 2, Desember 2019

E-ISSN : 2655-7347

Hibah Berdasarkan Pasal 920 Kitab Undang-Undang Hukum Perdata

Dilihat dari Asas Legitieme Portie (Studi Kasus: Putusan Mahkamah Agung Republik Indonesia Nomor 2954K/Pdt/2017)”.

\section{B. Perumusan Masalah}

Berdasarkan latar belakang sebagaimana telah diuraikan di atas, maka Penulis merumuskan pokok permasalahan ataupun rumusan masalahnya adalah "Bagaimana penerapan pemberian hibah berdasarkan Pasal 920 KUH Perdata dilihat dari asas Legitieme Portie (Studi kasus: Putusan Mahkamah Agung Republik Indonesia Nomor 2954K/Pdt/2017)?

\section{Metode Penelitian}

Metode penelitian merupakan suatu metode yang bertujuan untuk mempelajari satu atau beberapa gejala, dengan jalan menganalisanya dan dengan mengadakan pemeriksaan yang mendalam terhadap fakta tersebut, untuk kemudian mengusahakan suatu pemecahan atas masalah-masalah yang ditimbulkan oleh fakta tersebut. Penelitian merupakan sarana yang dipergunakan oleh manusia untuk memperkuat, membina serta mengembangkan ilmu pengetahuan. ${ }^{7)}$ Metode penelitian yang akan digunakan dalam penelitian ini sebagai berikut:

1. Jenis Penelitian

Jenis penelitian yang digunakan oleh Penulis adalah penelitian hukum normatif. Penelitian hukum normatif mencakup penelitian terhadap asas-asas hukum, penelitian terhadap sistematika hukum, penelitian terhadap taraf sinkronisasi hukum, penelitian sejarah hukum, dan penelitian perbandingan hukum. ${ }^{8)}$ Penulis menggunakan jenis

\footnotetext{
7) Soerjono Soekanto, Pengantar Penelitian Hukum, Cetakan ke-3, (Jakarta: UI Press, 1986),
} hal.3.

8) Ibid., hal.51. 
Volume 2 Nomor 2, Desember 2019

E-ISSN : 2655-7347

penelitian hukum normatif dikarenakan penelitian hukum ini menggunakan sumber data yang diperoleh melalui bahan-bahan kepustakaan.

\section{Sifat Penelitian}

Penelitian yang dilakukan oleh Penulis bersifat deskriptif. Penelitian deskriptif dimaksudkan untuk memberikan data yang seteliti mungkin tentang manusia, keadaan atau gejala-gejala lainnya. Hal tersebut maksudnya adalah mempertegas hipotesis-hipotesis agar dapat membantu memperkuat teori-teori lama, atau di dalam kerangka menyusun teori-teori baru. ${ }^{9)}$

\section{Jenis Data}

Jenis data yang digunakan oleh Penulis adalah data sekunder yang dalam penelitian hukum merupakan data yang diperoleh dari bahan pustaka. ${ }^{10}$ Di dalam penelitian hukum, data sekunder mencakup bahan hukum primer, bahan hukum sekunder, dan bahan hukum tersier dengan penjelasan sebagai berikut: ${ }^{11}$

a. Bahan hukum primer yaitu bahan-bahan hukum yang mengikat dan terdiri dari: norma (dasar) atau kaidah dasar; peraturan dasar; peraturan perundang-undangan; bahan hukum yang tidak dikodifikasikan; yurisprudensi; traktat; serta bahan hukum dari zaman penjajahan yang hingga kini masih berlaku seperti, Kitab Undang-Undang Hukum Pidana (yang merupakan terjemahan yang secara yuridis formal bersifat tidak resmi dari Wetboek van Strafrecht). Bahan hukum primer yang digunakan oleh Penulis yaitu Undang-Undang Nomor 2 Tahun 2014 tentang Perubahan Atas

\footnotetext{
9) Ibid., hal.10.

10) Ibid., hal.51.

11) Soerjono Soekanto dan Sri Mamudji, Penelitian Hukum Normatif: Suatu Tinjauan Singkat, (Jakarta: RajaGrafindo Persada, 2006), hal.13.
} 
Volume 2 Nomor 2, Desember 2019

E-ISSN : 2655-7347

Undang-Undang Nomor 30 Tahun 2004 tentang Jabatan Notaris, Kitab Undang-Undang Hukum Perdata, dan Putusan Mahkamah Agung Nomor: 2954K/Pdt/2017.

b. Bahan hukum sekunder yaitu bahan hukum yang memberikan penjelasan mengenai bahan hukum primer, seperti rancangan undang-undang, hasil-hasil penelitian, hasil karya dari kalangan hukum, dan seterusnya. Bahan hukum sekunder yang digunakan oleh Penulis yaitu buku-buku ilmiah di bidang hukum di Indonesia secara umum dan buku-buku tentang hukum waris.

c. Bahan hukum tersier yaitu bahan hukum yang memberikan petunjuk maupun penjelasan terhadap bahan hukum primer dan sekunder, seperti kamus, ensiklopedia, indeks kumulatif, dan seterusnya. Bahan hukum tersier yang digunakan oleh Penulis adalah Kamus Besar Bahasa Indonesia (KBBI).

4. Teknik Pengumpulan Data

Teknik pengumpulan data yang digunakan oleh Penulis adalah studi kepustakaan terhadap bahan-bahan hukum, baik bahan hukum primer, bahan hukum sekunder, maupun bahan hukum tersier. Studi kepustakaan merupakan teknik pengumpulan data dengan mengumpulkan bahan pustaka seperti buku, dokumen, dan artikel, serta membaca, mengkaji, mempelajari, dan mencatat dari buku-buku atau referensi yang ada kaitannya dengan objek atau permasalahan yang diteliti. $^{12)}$

5. Teknik Analisis Data

Teknik analisis data yang digunakan oleh Penulis adalah analisis secara kualitatif. Analisis secara kualitatif merupakan suatu tata cara

12) Soerjono Soekanto, Op.Cit., hal.21. 
Volume 2 Nomor 2, Desember 2019

E-ISSN : 2655-7347

penelitian yang menghasilkan data deskriptif. ${ }^{13)}$ Data deskriptif merupakan data yang dituangkan dalam bentuk narasi dan data yang diberikan seteliti mungkin tentang manusia, keadaan atau gejala-gejala lainnya. ${ }^{14)}$

\section{PEMBAHASAN}

Pemberian hibah adalah batal apabila hibah mengenai benda-benda baru akan ada di kemudian hari sebagaimana dimaksud dalam Pasal 1667 KUH Perdata, pemberi hibah tidak boleh memperjanjikan bahwa ia tetap berkuasa untuk menjual atau memberikan kepada orang lain suatu benda yang termasuk dalam hibah sebagaimana dimaksud dalam Pasal 1668 KUH Perdata, hibah tersebut dibuat dengan syarat bahwa si penerima hibah akan melunasi utangutang atau beban-beban lain, selain yang dinyatakan dengan tegas di dalam akta hibah sendiri ataupun di dalam suatu daftar yang ditempelkan padanya sebagimana dimaksd dalam Pasal 1670 KUH Perdata, serta hibah tersebut dinyatakan batal apabila tidak dibuat dalam bentuk akta notaris. Namun, pemberian-pemberian benda-benda bergerak tidak memerlukan suatu akta, dan adalah sah dengan penyerahan langsung kepada si penerima hibah sebagaimana diatur dalam Pasal 1687 KUH Perdata.

Sehingga pemberian hibah dapat dihapuskan ataupun dibatalkan apabila tidak memenuhi syarat-syarat penghibahan dilakukan seperti pemberian hibah tersebut memenuhi syarat-syarat hibah dinyatakan batal, apabila si penerima hibah telah bersalah melakukan atau membantu melakukan kejahatan yang bertujuan mengambil jiwa si penghibah (pemberi hibah) atau suatu kejahatan lain terhadap si penghibah, serta jika penerima hibah menolak untuk memberikan tunjangan nafkah kepada si penghibah (pemberi hibah) setelah orang ini jatuh dalam kemiskinan sebagaimana diatur dalam Pasal 1688 KUH Perdata.

\footnotetext{
13) Ibid., hal.250.
}

14) Ibid., hal.10. 
Volume 2 Nomor 2, Desember 2019

E-ISSN : 2655-7347

Berdasarkan penjelasan tersebut, diketahui bahwa batalnya suatu pemberian hibah sebagaimana diatur dalam KUH Perdata, tidak disebutkan adanya pelanggaran terhadap legitieme portie yang mengakibatkan batalnya suatu hibah. Hal tesebut dikarenakan pembatalan atas pemberian hibah yang melanggar legitieme portie hanya dapat terjadi apabila para ahli waris yang berhak atas harta warisan sebagai legitimaris tersebut melakukan penuntutan ke pengadilan. Sehingga sepanjang legitimaris tidak melakukan penuntutan atas pemberian hibah yang melanggar legitieme portienya, hibah tersebut tetap dapat dilaksanakan dan dinyatakan sah secara hukum. Pendapat Penulis ini telah diperkuat dengan adanya hasil wawancara Penulis dengan Ibu Notaris Ninik Sukadarwati, S.H., yang juga mengatakan bahwa pemberian hibah yang dilakukan oleh pemberi hibah kepada penerima hibah dan diwujudkan dalam bentuk akta notaris yaitu akta hibah yang tidak dapat dibatalkan oleh notaris secara sepihak. Tetapi dapat dibatalkan oleh pengadilan. Lalu apabila legitimaris tidak melakukan penuntutan pembatalan hibah ke pengadilan, maka hal tersebut menunjukkan bahwa pemberian hibah tersebut telah mendapatkan persetujuan dari semua legitimaris. Sehinga pemberian hibah tersebut tetap dapat dilaksanakan dan dinyatakan sah.

Selanjutnya setelah pemberian hibah dalam bentuk akta hibah telah dinyatakan batal oleh pengadilan, maka tindakan selanjutnya yang seharusnya dilaksanakan adalah melakukan inbreng sebagaimana dimaksud dalam Pasal 1086 KUH Perdata yang menyatakan bahwa hibah yang telah diperoleh dari pewaris semasa hidupnya, harus dimasukkan oleh para waris garis turun ke bawah, baik sah maupun luar kawin baik telah menerima warisannya secara murni maupun dengan hak istimewa untuk mengadakan pendaftaran, baik hanya memperoleh bagian mutlaknya maupun telah memperoleh lebih dari itu, kecuali pemberian tersebut telah dilakukan dengan pembebasan secara jelas dari pemasukan, atau apabila penerima hibah dalam akta autentik atau dalam surat 
Volume 2 Nomor 2, Desember 2019

E-ISSN : 2655-7347

wasiat telah dibebaskan dari kewajibannya untuk memasukkan; serta harus dimasukkan oleh semua waris lainnya, baik waris karena kematian maupun waris wasiat, namun hanya dalam hal pewaris sebagai pemberi hibah dengan tegas telah memerintahkan atau memperjanjikan dilakukannya pemasukkan.

Setelah dilaksanakannya inbreng atas hibah yang telah dinyatakan batal sebagaimana dimaksud dalam Pasal 1086 KUH Perdata tersebut, maka pembagian harta warisan dilakukan perhitungan kembali menurut ketentuan ahli waris $a b$ intestato dengan mana masing-masing ahli waris mendapatkan bagian yang sama besar. Kemudian berlakunya asas penderajatan bagi ahli waris yang mendapatkan harta warisan yaitu ahli waris yang derajatnya lebih dekat akan menutup ahli waris yang derajatnya lebih jauh dari pewaris sebagaimana diatur dalam Pasal 853 KUH Perdata. Tetapi, apabila hibah dibatalkan dan ahli waris mutlak yang berkedudukan sebagai legitimaris hanya menuntut bagian legitieme portienya yang terlanggar dengan adanya pemberian suatu hibah, maka wajib dilaksanakannya inkorting (pengurangan) terhadap harta warisan.

Pelaksanaan inkorting sebagaimana dimaksud dalam Pasal 920 KUH Perdata merupakan suatu pengurangan terhadap hibah maupun hibah wasiat yang mengakibatkan menjadi kurangnya bagian mutlak dalam sesuatu warisan, boleh dilakukan pengurangan, bilamana warisan itu jatuh meluang (terbuka), dengan adanya tuntutan dari para ahli waris mutlak dan ahli waris karena penggantian dari ahli waris mutlak tersebut. Inkorting terhadap penerima hibah yang merupakan legitimaris juga dapat dilaksanakan. Hal tersebut diatur dalam Pasal 926 KUH Perdata yang menyatakan bahwa pengurangan yang dilakukan terhadap pengangkatan sebagai ahli waris dan penerima hibah wasiat tanpa membeda-bedakan antara pengangkatan ahli waris dan penerima hibah wasiat.

Penggunaan inkorting bertujuan untuk memberikan perlindungan bagi legitimaris sebagai ahli waris yang memiliki bagian mutlak dalam mendapatkan harta warisan serta dengan adanya inkorting dapat memenuhi asas keadilan bagi 
Volume 2 Nomor 2, Desember 2019

E-ISSN : 2655-7347

pihak penerima hibah dan pihak legitimaris, dengan mana kedua pihak tersebut mendapatkan bagian atas harta warisan. Pelaksanaan inkorting terhadap hibah dapat dilakukan dengan cara mengurangi bagian yang diterima oleh penerima hibah, yang didahului dengan adanya pelaksanaan inbreng (pemasukan hibah) yang dilakukan dengan mengembalikan hal-hal yang telah dinikmati ke dalam harta peninggalan sebagaimana diatur dalam Pasal 1092 KUH Perdata. Pemasukan hibah (inbreng) yang berupa benda bergerak menurut Pasal 1095 KUH Perdata dilakukan atas pilihan dari yang memasukkan dengan mengembalikan harganya ketika pemberian dilakukan, atau dengan mengembalikan benda-benda tersebut ke dalam wujudnya semula.

Namun, untuk pemasukan hibah (inbreng) atas suatu benda tidak bergerak dapat dilakukan dengan mengembalikan ke dalam wujud yang semula maupun dengan memasukkan harga ketika benda tersebut diberikan sebagaimana diatur dalam Pasal 1093 KUH Perdata. Setelah hibah-hibah yang pernah diberikan kepada ahli waris dimasukkan dalam harta warisan dan dihitung, maka langkah selanjutnya yang dilaksanakan adalah menambahkan aktiva dari harta warisan ke dalam perhitungan semua hibah yang telah dimasukkan dalam harta warisan. Selanjutnya akan dilakukan pengurangan dari utang-utangnya pewaris. Setelah semua tahap tersebut dilaksanakan, maka harta warisan tersebut dinamakan harta warisan bersih. Langkah selanjutnya yang dapat dilakukan adalah dengan menghitung bagian legitieme portie dari para legitimaris yang seharusnya mendapatkan bagian mutlak dari harta warisan. Berdasarkan harta warisan bersih tersebut akan dibagi kepada legitimarisnya sesuai dengan bagian legitieme portie, dan sisanya akan tetap diterima oleh penerima hibah, dengan mana bagian sisa yang diterima penerima hibah merupakan hasil inkorting yang telah dilakukan.

Namun, perlu diketahui bahwa penerima hibah tetap mendapatkan bagian lebih besar daripada bagian legitimaris lainnya. Hal tersebut dikarenakan penerima hibah mendapatkan bagian legitieme portienya sebagai ahli waris yang 
Volume 2 Nomor 2, Desember 2019

E-ISSN : 2655-7347

berhak atas bagian mutlak, dan mendapatkan bagian yang merupakan hibah untuknya dari pemberi hibah. Pendapat Penulis tersebut juga telah diperkuat dengan adanya pendapat dari Ibu Dr. Endang Pandamdari, S.H., CN, M.H. yang menyatakan pendapatnya bahwa setelah pemberian hibah dalam bentuk akta hibah dinyatakan batal, maka ahli waris yang legitieme portienya tersinggung hanya mendapatkan bagian legitieme portienya. Sedangkan penerima hibah sebagai salah seorang ahli waris yang berhak atas bagian mutlak suatu harta warisan bersih akan mendapatkan bagian yang lebih besar daripada ahli waris lainnya. Hal tersebut dikarenakan penerima hibah sebagai salah seorang ahli waris tersebut mendapatkan bagiannya dari legitieme portie dan mendapatkan bagian hibahnya.

Dengan demikian dapat diketahui bahwa penerapan inkorting terhadap pemberian hibah yang melanggar legitieme portie merupakan hal yang penting dan wajib untuk dilaksanakan sebagai suatu solusi dalam menghadapi permasalahan mengenai pemberian hibah yang melanggar legitieme portie para legitimarisnya. Namun, penerapan inkorting dalam hal pemberian hibah yang melanggar legitieme portie tidak dinyatakan secara tegas dalam Putusan Mahkamah Agung Republik Indonesia Nomor 2954K/Pdt/2017. Dalam putusan tersebut hanya diputuskan mengenai pembagian harta warisan menurut legitieme portie dari Para Penggugat dan Tergugat saja. Tetapi tidak dijelaskan lebih lanjut mengenai adanya peranan dari inkorting yang sebenarnya harus dilaksanakan dalam pembagian warisan atas pemberian hibah yang diberikan oleh Almarhumah Tjoa Ay Nio kepada Euphemia Megasari selaku Tergugat dengan mana pemberian hibah tersebut telah melanggar legitieme portie Risa Pahala (Lim Bie Nio) dan Lim Le Tjoe selaku Para Penggugat.

Berdasarkan penjelasan di atas mengenai pentingnya penggunaan inkorting sebagai solusi dalam menyelesaikan permasalahan terkait dengan pemberian hibah kepada Tergugat yang melanggar legitieme portie Para Penggugat, maka 
Volume 2 Nomor 2, Desember 2019

E-ISSN : 2655-7347

penerapan pemberian hibah berdasarkan Pasal 920 KUH Perdata mengenai inkorting terhadap kasus Putusan Mahkamah Agung Republik Indonesia Nomor 2954K/Pdt/2017 dapat dijelaskan sebagai berikut:

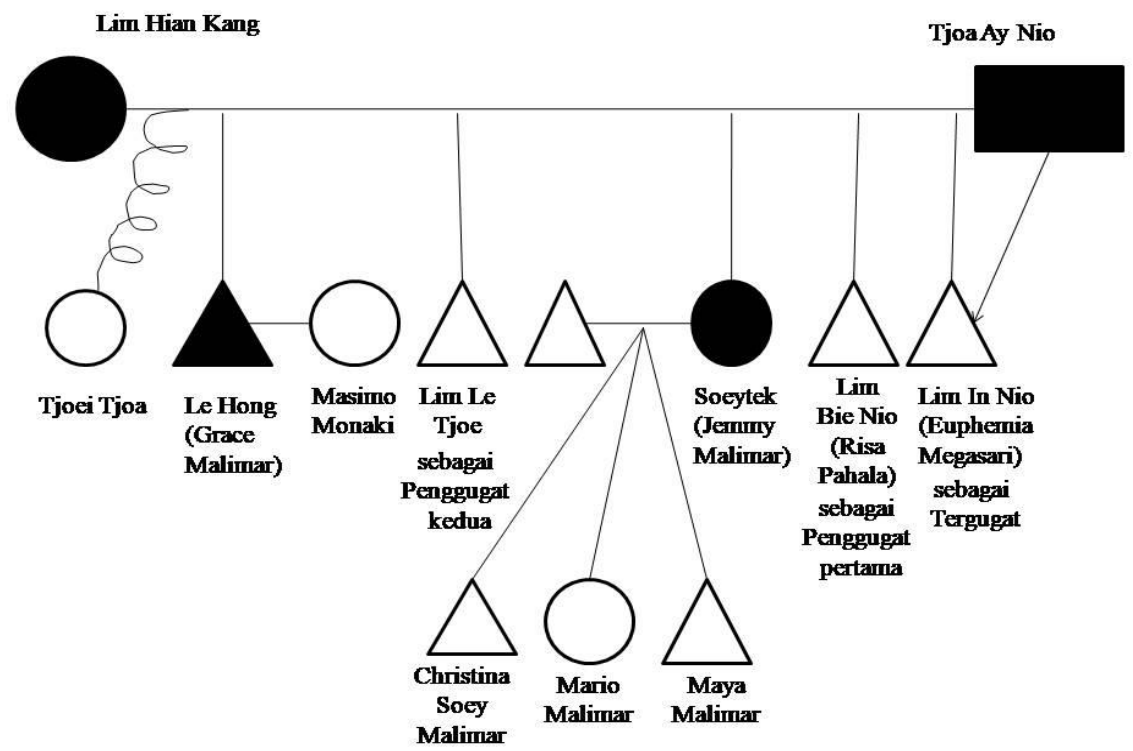

Berdasarkan gambar di atas, dapat diketahui bahwa Almarhum Lim Hian Kang dan Almarhumah Tjoa Ay Nio memiliki seorang anak angkat yaitu Tjoei Tjoa. Istilah anak angkat atau yang biasanya disebut dengan adopsi, tidak dikenal dalam KUH Perdata. Tetapi adanya peraturan yang mengatur mengenai pengangkatan anak dimulai pada tahun 1917, dengan mana KUH Perdata dinyatakan berlaku untuk warga negara keturunan Tionghoa, sementara warga keturunan Tionghoa telah mengenal dan mempraktekkan adanya kelembagaan anak angkat (adopsi) sejak lama. Sehingga sejak saat itulah pemerintah Hindia Belanda memberlakukan Staatsblad 1917 Nomor 129 yang memberlakukan KUH Perdata atas golongan Timur Asing Tionghoa, yang di dalamnya terdapat pasal-pasal yang mengatur hal-hal yang berkaitan dengan pengangkatan anak. Staatsblad tersebut juga memungkinkan pengangkatan anak oleh seseorang yang terikat perkawinan serta bagi yang pernah terikat perkawinan yaitu duda atau 
Volume 2 Nomor 2, Desember 2019

E-ISSN : 2655-7347

janda. Namun bagi janda yang suaminya telah meninggal dan suami meninggalkan wasiat yang isinya tidak menghendaki adanya pengangkatan anak, maka janda tersebut tidak dapat melakukannya. Menurut peraturan adopsi tersebut, diketahui bahwa hanya anak laki-laki yang dapat diangkat sebagai anak dan hanya dapat dilakukan dengan akta notaris. Namun berdasarkan Surat Edaran Mahkamah Agung (SEMA) Nomor 6 Tahun 1983 menyatakan bahwa anak perempuan dapat diadopsi. ${ }^{15}$

Sehingga seorang anak angkat yang diakui secara sah oleh orang tua angkatnya dapat menerima harta warisan, tetapi untuk anak angkat yang tidak diakui secara sah oleh orang tua angkatnya maka tidak dapat menerima harta warisan. Atas dasar hal tersebut dengan mana Tjoei Tjoa yang berkedudukan sebagai anak angkat, dan tidak ditemukannya dokumen-dokumen yang menyatakan bahwa ia merupakan anak angkat yang diakui secara sah oleh orang tua angkatnya, maka ia tidak berhak atas harta warisan milik Almarhumah Tjoa Ay Nio selaku pewaris. Selanjutnya mengenai anak dari Almarhum Lim Hian Kang dan Almarhumah Tjoa Ay Nio yang bernama Le Hong (Grace Malimar) telah meninggal dunia pada tahun 2008 dan tidak mempunyai keturunan. Sehingga tidak ada ahli waris pengganti yang dapat menggantikan posisi Almarhumah Le Hong (Grace Malimar) untuk mendapatkan harta warisan dari pewaris. Namun, anak dari Almarhum Lim Hian Kang dan Almarhumah Tjoa Ay Nio yang bernama Soeytek (Jemmy Malimar) yang telah meninggal dunia, memiliki 3 (tiga) orang anak yaitu Christina Soey Malimar, Mario Malimar, dan Maya Malimar.

Sehingga adanya ahli waris pengganti yang dapat menggantikan posisi Almarhum Soeytek (Jemmy Malimar) untuk mendapatkan harta warisan dari pewaris. Orang-orang yang termasuk ahli waris pengganti adalah orang-orang

15) M. Fahmi Al Amruzi, “Anak Angkat Di Persimpangan Hukum”, Jurnal MMH, Volume 43, Nomor 1 (Januari 2014): 108, diakses tanggal 8 November 2019, doi: 10.14710/mmh.43.1.2014.107114. 
Volume 2 Nomor 2, Desember 2019

E-ISSN : 2655-7347

yang mewaris berdasarkan penggantian tempat dari ahli waris yang seharusnya menerima harta warisan yang telah meninggal dunia. Sehingga orang-orang yang merupakan keturunan dari ahli waris yang seharusnya menerima harta warisan yang telah meninggal dunia tersebut, dapat maju menjadi ahli waris pengganti. Biasanya ahli waris berdasarkan penggantian tempat ini menganut asas penderajatan yaitu keluarga yang derajatnya lebih dekat menutup keluarga yang derajatnya lebih jauh. Ahli waris pengganti mempunyai hak untuk bertindak sebagai pengganti, dalam derajat dan dalam segala hak orang yang diganti sebagaimana dimaksud dalam Pasal 841 KUH Perdata.

Meskipun Almarhum Soeytek (Jemmy Malimar) telah tinggal menetap di Jerman dan telah menjadi Warga Negara Jerman. Namun hal tersebut tidak menutup bagi Christina Soey Malimar, Mario Malimar, dan Maya Malimar untuk menjadi ahli waris pengganti dari Almarhum Soeytek (Jemmy Malimar) dalam mendapatkan harta warisan dari pewaris yang berupa uang hasil pelelangan sebidang tanah dan bangunan rumah. Hal tersebut dikarenakan dasar hak mewaris adalah adanya hubungan darah dengan pewaris dalam garis lurus ke atas atau keluarga sedarah dalam garis lurus ke bawah yaitu keturunan-keturunan sah. Pendapat Penulis tersebut juga telah diperkuat dengan adanya pendapat dari Ibu Khairani Bakri, S.H., M.H. yang menyatakan pendapatnya bahwa apabila anak dari pewaris telah pindah kewarganegaraan menjadi Warga Negara Asing tetap berhak untuk mendapatkan warisan berupa uang, dikarenakan adanya hubungan darah.

Kemudian untuk bagian Lim Bie Nio (Risa Pahala) dan Lim Le Tjoe sebagai Para Penggugat yang merupakan anak-anak dari Almarhum Lim Hian Kang dan Almarhumah Tjoa Ay Nio juga berhak untuk mendapatkan warisan. Mereka mewaris berdasarkan kedudukan sendiri yang berarti bahwa ahli waris tersebut mempunyai hak untuk mewaris yang merupakan haknya sendiri dan bukan dikarenakan menggantikan hak orang lain sebagaimana dimaksud dalam Pasal 
Volume 2 Nomor 2, Desember 2019

E-ISSN : 2655-7347

852 KUH Perdata. Hal tersebut berlaku pula bagi Euphemia Megasari (Lim In Nio) sebagai Tergugat yang juga merupakan anak-anak dari Almarhum Lim Hian Kang dan Almarhumah Tjoa Ay Nio yang berhak untuk mendapatkan warisan berdasarkan kedudukan sendiri. Biasanya bagi ahli waris berdasarkan kedudukan sendiri mendapatkan harta warisan dengan istilah mewaris kepala demi kepala yang maksudnya adalah ahli waris tersebut mendapatkan harta warisan dengan bagian yang sama besarnya.

Berdasarkan gambar di atas, dapat juga diketahui bahwa Almarhumah Tjoa Ay Nio telah memberikan hibah kepada Euphemia Megasari (Lim In Nio) selaku Tergugat berupa sebidang tanah dan bangunan rumah yang terletak di Jalan A.M. Sangaji Nomor 5, Kelurahan Petojo Utara, Kecamatan Gambir, Jakarta Pusat sesuai Sertifikat Hak Guna Bangunan (HGB) Nomor 1136/Desa Petojo Utara, seluas $925 \mathrm{~m}^{2}$ (sembilan ratus dua puluh lima meter persegi), Surat Ukur tanggal 23 Maret 1982 Nomor 944/1982, atas nama Tjoa Ay Nio dengan Akta Hibah Nomor 97/H/HGB/1989 tertanggal 7 Desember 1989. Kemudian tanah dan bangunan rumah yang terletak di Jalan A.M. Sangaji Nomor 5, Kelurahan Petojo Utara, Kecamatan Gambir, Jakarta Pusat tersebut telah dibalik nama dan ditingkatkan haknya menjadi Sertifikat Hak Milik Nomor 697/Petojo atas nama Euphemia Megasari dan seluruhnya telah dikuasai dan ditempati oleh Tergugat.

Tentunya dengan pemberian hibah dari Almarhumah Tjoa Ay Nio kepada Tergugat telah merugikan legitieme portie dari Para Penggugat dan ahli waris lainnya sebagai legitimaris. Namun, dalam pertimbangan hukum hakim pada putusan tersebut menyatakan bahwa atas sebidang tanah dan bangunan rumah yang terletak di Jalan A.M. Sangaji Nomor 5, Kelurahan Petojo Utara, Kecamatan Gambir, Jakarta Pusat sesuai Sertifikat Hak Guna Bangunan (HGB) Nomor 1136/Desa Petojo Utara, seluas $925 \mathrm{~m}^{2}$ (sembilan ratus dua puluh lima meter persegi), Surat Ukur tanggal 23 Maret 1982 Nomor 944/1982, atas nama Tjoa Ay Nio yang merupakan harta warisan yang belum terbagi, yang telah 
Volume 2 Nomor 2, Desember 2019

E-ISSN : 2655-7347

dibalik nama dan ditingkatkan haknya menjadi Sertifikat Hak Milik Nomor 697/Petojo atas nama Euphemia Megasari harus diserahkan dalam keadaan baik dan tanpa beban kepada Para Penggugat, untuk selanjutnya dibagi menurut bagiannya masing-masing yaitu kepada Para Penggugat dan Tergugat, dan apabila tidak dapat dilaksanakan maka dapat dilelang di depan umum dan hasil penjualannya dibagi kepada Para Penggugat dan Tergugat sesuai bagiannya masing-masing.

Pertimbangan hukum hakim sebagaimana yang dinyatakan di atas, Penulis tidak sependapat dengan hakim dikarenakan penyerahan sebidang tanah dan bangunan kepada Para Penggugat yang apabila tidak dapat dilaksanakan maka dapat dilelang di depan umum dan hasil penjualannya hanya dibagikan kepada Para Penggugat dan Tergugat saja. Tidak disebutkan pembagian hasil penjualannya kepada ahli waris lainnya yaitu adanya ahli waris pengganti yang merupakan anak kandung dari Almarhum Soeytek (Jemmy Malimar) yang terdiri dari Christina Soey Malimar, Mario Malimar, dan Maya Malimar. Meskipun ahli waris pengganti dari Almarhum Soeytek (Jemmy Malimar) merupakan Warga Negara Jerman, tetapi dasar hak mewaris adalah berdasarkan kepada hubungan darah. Sehingga ahli waris pengganti dari Almarhum Soeytek (Jemmy Malimar) tetap berhak atas harta warisan.

Selanjutnya hakim dalam memberikan putusan menyatakan bahwa menetapkan bagian mutlak (legitieme portie) untuk Penggugat pertama, Penggugat kedua masing-masing 3/4 bagian dari bagian yang menjadi haknya dari pewarisan harta peninggalan Almarhum Lim Hian Kang dan Almarhumah Tjoa Ay Nio. Berdasarkan penjelasan tersebut, maka Penulis juga tidak sependapat dengan putusan hakim dikarenakan dalam putusan tersebut tidak dicantumkan pula mengenai bagian legitieme portie ahli waris pengganti dari Almarhum Soeytek (Jemmy Malimar), dengan mana ahli waris pengganti dari Almarhum Soeytek (Jemmy Malimar) berhak atas bagian legitieme portie 
Volume 2 Nomor 2, Desember 2019

E-ISSN : 2655-7347

dikarenakan bagian legitieme portie dapat dilangsungkan berdasarkan penggantian ke bawah sebagaimana diatur dalam Pasal 914 KUH Perdata. Sehingga putusan yang tidak dinyatakan secara jelas dan tegas tersebut dapat menimbulkan tidak tercapainya kepastian hukum. Hal tersebut dikarenakan tanpa pernyataan yang jelas mengenai bagian legitieme portie ahli waris pengganti dari Almarhum Soeytek, akan memiliki pengaruh terhadap hitungan bagian legitieme portie yang seharusnya diterima oleh ahli waris baik kepada Para Penggugat, Tergugat maupun kepada ahli waris pengganti yang juga berhak atas harta warisan.

Berdasarkan hal tersebut, maka wajib untuk melaksanakan inkorting sebagaimana diatur dalam Pasal 920 KUH Perdata dalam menyelesaikan permasalahan terkait dengan pemberian hibah kepada salah seorang ahli waris yang melanggar legitieme portie ahli waris lainnya. Meskipun dalam putusan hakim tidak dinyatakan secara tertulis mengenai pelaksanaan inkorting sebagaimana diatur dalam Pasal 920 KUH Perdata, pelaksanaan inkorting tersebut tetap wajib untuk dilaksanakan oleh ahli waris yang bersangkutan. Hal tersebut ditandai dengan diputuskannya oleh hakim mengenai pembagian menurut legitieme portie maka secara otomatis berlakulah Pasal $920 \mathrm{KUH}$ Perdata mengenai inkorting tersebut untuk menyelesaikan permasalahan pembagian warisan dikarenakan adanya pemberian hibah kepada salah seorang ahli waris yang melanggar legitieme portie ahli waris lainnya. Sehingga dapat diketahui bahwa pelaksanaan inkorting sebagaimana diatur dalam Pasal 920 KUH Perdata mempunyai hubungan dan telah sesuai dengan asas legitieme portie.

Dengan demikian berdasarkan kasus Putusan Mahkamah Agung Republik Indonesia Nomor 2954K/Pdt/2017 dengan mana adanya akta hibah yang dibatalkan, maka pembagian harta warisan kepada ahli warisnya harus didahulukan dengan adanya pelaksanaan inbreng yaitu memasukkan kembali 
Volume 2 Nomor 2, Desember 2019

E-ISSN : 2655-7347

hibah-hibah yang telah diberikan oleh pewaris ketika masih hidup. Namun, berdasarkan kasus putusan Mahkamah Agung Republik Indonesia Nomor 2954K/Pdt/2017 tidak dinyatakan adanya pemberian hibah semasa hidup lainnya yang dilakukan oleh pewaris (Almarhumah Tjoa Ay Nio) kepada ahli warisnya selain hibah yang berupa sebidang tanah dan bangunan rumah, maka inbreng yang dapat dilaksanakan hanya berupa pemasukan hibah atas sebidang tanah dan bangunan rumah tersebut dalam keadaan baik dan terbebas dari beban apapun.

Lalu setelah dilaksanakannya inbreng, maka pembagian harta warisan kepada ahli waris mutlak dilakukan berdasarkan ketentuan sebagaimana dimaksud dalam Pasal 852 KUH Perdata, dengan mana ahli waris mutlak yang dimaksud adalah anak-anak beserta keturunannya. Dalam kasus tersebut diketahui bahwa pewaris (Almarhumah Tjoa Ay Nio) memiliki 5 (lima) orang anak kandung yaitu Euphemia Megasari (Lim In Nio), Lim Bie Nio (Risa Pahala), Lim Le Tjoe, Almarhum Soeytek (Jemmy Malimar), dan Almarhumah Le Hong (Grace Malimar). Meskipun Almarhum Soeytek (Jemmy Malimar) telah meninggal dunia, ia tetap mendapatkan bagian atas harta warisannya dikarenakan adanya ahli waris pengganti yang merupakan anak kandung dari Almarhum Soeytek (Jemmy Malimar) yang terdiri dari 3 (tiga) orang anak yaitu Christina Soey Malimar, Mario Malimar, dan Maya Malimar. Namun dikarenakan Almarhumah Le Hong (Grace Malimar) telah meninggal dunia dan tidak memiliki keturunan, maka Almarhumah Le Hong (Grace Malimar) tidak mendapatkan bagian atas harta warisannya. Sehingga pembagian harta warisan kepada ahli waris mutlak yang merupakan anak-anak kandung beserta keturunannya dari pewaris sebagaimana dimaksud dalam Pasal 852 KUH Perdata atas harta warisan dari pewaris hanya dibagikan kepada 4 (empat) orang anak, dengan mana setiap anak mendapatkan 1/4 bagian dari harta warisan.

Namun, dalam kasus Putusan Mahkamah Agung Republik Indonesia Nomor 2954K/Pdt/2017, diketahui bahwa dikabulkannya pembatalan hibah dan Para 
Volume 2 Nomor 2, Desember 2019

E-ISSN : 2655-7347

Penggugat sebagai ahli waris mutlak yang berkedudukan sebagai legitimaris hanya menuntut bagian legitieme portienya yang terlanggar dengan adanya pemberian suatu hibah. Dengan demikian langkah yang wajib untuk dilaksanakan adalah melaksanakan inkorting (pengurangan) terhadap harta warisan sebagaimana dimaksud dalam Pasal 920 KUH Perdata dalam hal hanya untuk memenuhi bagian legitieme portie yang dituntut oleh Para Penggugat. Maka penerapan pemberian hibah berdasarkan Pasal 920 KUH Perdata yang dilaksanakan dalam kasus Putusan Mahkamah Agung Republik Indonesia Nomor 2954K/Pdt/2017 dimulai dengan melakukan inbreng terhadap hibah yang telah diberikan sebelumnya, lalu akan dihitung penambahan aktiva dan dikurangi dengan utang-utang pewaris. Namun, berdasarkan putusan tersebut tidak dinyatakan pula mengenai adanya aktiva-aktiva yang dimiliki oleh pewaris maupun utang-utang yang harus dilunasi oleh pewaris. Sehingga sebidang tanah dan bangunan rumah tersebut yang telah dikembalikan dalam wujudnya semula, telah dinyatakan sebagai harta warisan bersih. Selanjutnya akan dilaksanakan langkah berikutnya yaitu menghitung bagian legitieme portie dari legitimaris.

Euphemia Megasari (Lim In Nio), Lim Bie Nio (Risa Pahala), Lim Le Tjoe, dan Almarhum Soeytek (Jemmy Malimar) mendapatkan bagian legitieme portie sebesar 3/4 bagian dikarenakan terdiri dari 3 (tiga) anak kandung atau lebih sebagaimana diatur dalam Pasal 914 KUH Perdata. Lalu mendapatkan bagian yang seharusnya diperoleh dari harta warisan sebesar 1/4 bagian dikarenakan pewaris memiliki ahli waris sebanyak 4 orang anak yang terdiri dari Euphemia Megasari (Lim In Nio), Lim Bie Nio (Risa Pahala), Lim Le Tjoe serta Soeytek (Jemmy Malimar) yang akan digantikan oleh Christina Soey Malimar, Mario Malimar, dan Maya Malimar sebagaimana diatur dalam Pasal 852 KUH Perdata. Sedangkan bagi ahli waris pengganti dari Almarhum Soeytek (Jemmy Malimar) hanya mendapatkan bagian dari Almarhum Soeytek (Jemmy Malimar) saja dan 
Volume 2 Nomor 2, Desember 2019

E-ISSN : 2655-7347

akan dibagi 3 (tiga) orang yaitu untuk Christina Soey Malimar, Mario Malimar, dan Maya Malimar sebagaimana diatur dalam Pasal 842 KUH Perdata.

Sehingga bagian legitieme portie tersebut merupakan bagian yang hanya boleh diterima oleh legitimaris yang terdiri dari Lim Bie Nio (Risa Pahala), Lim Le Tjoe dan ahli waris pengganti dari Almarhum Soeytek (Jemmy Malimar) yang terdiri dari Christina Soey Malimar, Mario Malimar dan Maya Malimar atas harta warisan. Sedangkan bagian yang akan diterima oleh Euphemia Megasari (Lim In Nio) sebagai legitimaris sekaligus sebagai penerima hibah adalah bagian legitieme portienya ditambah dengan sisa harta warisan yang telah dikurangi (diinkorting) bagian-bagian legitieme portie yang dibagikan kepada legitimaris lainnya

\section{PENUTUP}

\section{A. Kesimpulan}

Berdasarkan pembahasan mengenai permasalahan yang telah dikemukakan sebelumnya, maka Penulis menarik kesimpulan bahwa hibah yang dinyatakan batal oleh Majelis Hakim sebagaimana terdapat dalam kasus Putusan Mahkamah Agung Republik Indonesia Nomor 2954K/Pdt/2017, dengan mana Lim Bie Nio (Risa Pahala) sebagai Penggugat pertama dan Lim Le Tjoe sebagai Penggugat kedua yang merupakan ahli waris mutlak dan berkedudukan sebagai legitimaris hanya menuntut bagian legitieme portienya yang terlanggar dengan adanya pemberian suatu hibah. Sehingga langkah yang wajib untuk dilaksanakan adalah melaksanakan inkorting (pengurangan) terhadap harta warisan sebagaimana dimaksud dalam Pasal 920 KUH Perdata dalam hal hanya untuk memenuhi bagian legitieme portie yang dituntut oleh Para Penggugat. Pelaksanaan inkorting dimulai dengan tahap pemasukan hibah (inbreng) semua hibah yang telah diberikan oleh pewaris kepada ahli waris 
Volume 2 Nomor 2, Desember 2019

E-ISSN : 2655-7347

ketika masih hidup, lalu akan dihitung penambahan aktiva dan dikurangi dengan utang-utang pewaris, kemudian menghitung bagian legitieme portie dari legitimaris.

Dengan demikian bagian legitieme portie tersebut merupakan bagian yang hanya boleh diterima oleh legitimaris yang terdiri dari Lim Bie Nio (Risa Pahala), Lim Le Tjoe dan ahli waris pengganti dari Almarhum Soeytek (Jemmy Malimar) yang terdiri dari Christina Soey Malimar, Mario Malimar dan Maya Malimar atas harta warisan. Sedangkan bagian yang akan diterima oleh Euphemia Megasari (Lim In Nio) sebagai legitimaris sekaligus sebagai penerima hibah adalah bagian legitieme portienya ditambah dengan sisa harta warisan yang telah dikurangi (di-inkorting) bagian-bagian legitieme portie yang dibagikan kepada legitimaris lainnya.

Sehingga meskipun dalam putusan hakim tidak dinyatakan secara tertulis mengenai pelaksanaan inkorting sebagaimana diatur dalam Pasal 920 KUH Perdata, pelaksanaan inkorting tersebut tetap wajib untuk dilaksanakan oleh ahli waris yang bersangkutan. Hal tersebut ditandai dengan diputuskannya oleh hakim mengenai pembagian menurut legitieme portie maka secara otomatis berlakulah Pasal 920 KUH Perdata mengenai inkorting. Dengan demikian dapat diketahui bahwa Putusan Mahkamah Agung Republik Indonesia Nomor 2954K/Pdt/2017 dalam memberikan putusan mengenai pembagian harta warisan atas hibah yang dinyatakan cacat secara hukum maupun batal, secara teknis telah sesuai dengan ketentuan yang terdapat dalam KUH Perdata. Namun, dalam pertimbangan hukum hakim dan putusan pada tingkat Pengadilan Negeri yang diperkuat sampai tingkat kasasi di Mahkamah Agung yang tidak menyatakan secara jelas dan tegas bagian ahli waris pengganti dari Almarhum Soeytek (Jemmy Malimar) dapat menimbulkan tidak tercapainya kepastian hukum. Hal tersebut dikarenakan tanpa pernyataan yang jelas mengenai bagian ahli 
Volume 2 Nomor 2, Desember 2019

E-ISSN : 2655-7347

waris pengganti dari Almarhum Soeytek, akan memiliki pengaruh terhadap hitungan bagian yang seharusnya diterima oleh ahli waris baik kepada Para Penggugat, Tergugat maupun kepada ahli waris pengganti yang juga berhak atas harta warisan.

\section{B. Saran}

Berdasarkan kesimpulan yang telah diuraikan tersebut, maka saran yang dapat diberikan oleh Penulis adalah sebaiknya bagi masyarakat yang akan menjadi pewaris agar dapat membagikan harta warisan kepada ahli warisnya maupun memberikan hibah semasa hidupnya kepada penerima hibah secara adil dan merata berdasarkan ketentuan yang diatur dalam KUH Perdata. Hal tersebut dimaksudkan agar dapat dihindarinya permasalahan-permasalahan mengenai pemberian hibah yang melanggar legitieme portie yang merupakan bagian mutlak dari ahli waris yang bersangkutan. Selain itu, perlu juga bagi notaris dalam menjalankan tugas jabatannya untuk memberikan informasi-informasi mengenai eksistensi legitieme portie terlebih dahulu kepada pemberi hibah ketika akan membuat akta hibah serta diperlukannya persetujuan dari semua ahli waris dalam hal pembuatan akta hibah. Hal tersebut bertujuan agar pemberian hibah tersebut terhindar dari permasalahan-permasalahan mengenai pemberian hibah yang melanggar legitieme portie dari ahli waris yang bersangkutan.

Selanjutnya untuk Majelis Hakim Pengadilan Negeri untuk dapat memberikan pertimbangan hukum yang lebih tepat dan jelas sehingga dapat memberikan suatu kepastian hukum baik bagi para pihak yang berperkara yaitu Para Penggugat dan Tergugat maupun bagi ahli waris lainnya yang juga memiliki kedudukan untuk mendapatkan bagian yang 
Volume 2 Nomor 2, Desember 2019

E-ISSN : 2655-7347

menjadi haknya yaitu bagian legitieme portienya, meskipun ahli waris tersebut tidak ikut menjadi pihak yang berperkara.

\section{DAFTAR PUSTAKA}

\section{A. Buku}

Afandi, Ali. Hukum Waris, Hukum Keluarga dan Hukum Pembuktian. Cetakan ke-4. (Jakarta: Rineka Cipta, 2000.)

Ali, Zainuddin. Pelaksanaan Hukum Waris di Indonesia. (Jakarta: Sinar Grafika, 2008.)

Satrio, J. Hukum Waris. Cetakan ke-2. (Bandung: Alumni, 1992.)

Soekanto, Soerjono. Pengantar Penelitian Hukum. (Jakarta: UI-Press, 1986.)

Soekanto, Soerjono dan Sri Mamudji. Penelitian Hukum Normatif: Suatu Tinjauan Singkat. (Jakarta: RajaGrafindo Persada, 2006.)

Subekti, R dan R. Tjitrosudibio. Kitab Undang-Undang Hukum Perdata (Burgerlijk Wetboek). (Jakarta: Balai Pustaka, 2009.)

Suparman, Eman. Hukum Waris Indonesia: Dalam Perspektif Islam, Adat dan BW. (Bandung: Refika Aditama, 2018.)

\section{B. Artikel Jurnal Online}

Amruzi, M. Fahmi Al. “Anak Angkat Di Persimpangan Hukum”. Jurnal MMH. Volume 43, Nomor 1 (Januari 2014): 108. Diakses tanggal 8 November 2019. doi: 10.14710/mmh.43.1.2014.107-114 